\title{
Who is King of Sarawak's Rainforest? An insight to Sarawak's land corruption led by its Chief Minister and his family
}

Tisha Raj*

MacEwan University, Canada

\begin{abstract}
Malaysia's $13^{\text {th }}$ General Elections were hopes of many to be the turning point of change, breaking Barisan Nasional's (BN or National Front) 56 years of governance. $\mathrm{BN}$ in recent years had been plagued with allegations of corruption and cronyism. Land grabs in the state of Sarawak, exposed an intricate and systematic corruption that happens in all levels of government in Malaysia. The perils of the rainforest in Sarawak are uncovered through a corrupt systematic mass deforestation through the governance of its Chief Minister Taib Mahmud. Was Malaysia's latest election successful in dethroning Taib and his family out of their political powers? Taib holding several portfolios puts him in immense political and economic power. For more than 30 years, Taib has made use of his various ministerial roles to methodically harvest the state's natural resources and amassing a personal fortune of USD $\$ 15$ billion. The first family of Sarawak too has their share in Taib's fortunes. Kickbacks, corrupt land deals, evasion of Malaysian tax and the service economy of corruption were true and evident in the family's dealings. Taib's eldest daughter, Jamilah Taib and her husband Sean Murray, well known socialites in Ottawa, Canada play a major role in the slow death of Sarawak's rainforest and indigenous tribes. One woman, Clare Rewcastle
\end{abstract}


Brown who manages Sarawak Report and Radio Free Sarawak is determined to bring down the supreme rule of Taib and his family. Her media outlets aim “... to provide that platform and to offer an alternative vision of justice, transparency and a fairer future in Sarawak."

\section{Malaysia's Political Shakeups}

The $12^{\text {th }}$ general elections in Malaysia witnessed one of its biggest political shakeups in history. "After a 13 day campaign with a 70 percent voter turnout, the outcome was shocking, ..." (Marck, as cited in Singh, 2009, p. 157). So shocking, " "Political tsunami” is how theSunday Star summed things up" (The Economist, 2008, para. 1). The term 'political tsunami' gained notoriety among the Malaysian national press, local social media forums and the world over. Despite winning 140 of the 222 seats in the federal

parliament, the coalition party Barisan Nasional (BN or National Front) yielded one of the worst results since gaining independence in 1957 (The Economist, 2008, para. 2). The severity of this loss was reflected when "...the stockmarket fell by 10 percent on Monday as investors worried about the danger of unrest and instability" (The Economist, 2008, para. 2). The significant loss can be reflected in numbers, in $2004 \mathrm{BN}$ won 64 percent of the votes and 90 percent of the parliamentary seats however, in 2008 it won only 51 percent of the votes and 63 percent of parliamentary seats; losing two thirds supermajority (The Economist, 2008, para. 3-4).

Singh (2009, p. 163) pointed out that one of the major reasons for BN's alarming loss was due to the voters being angered by the rampant corruption and abuse of power. Former Prime Minister Abdullah Ahmad Badawi took a stance "...to clean up the system under his National Intergrity Plan (Singh, 2009, p. 159) and set up an independent Anti-Corruption Agency (ACA)" (Balfour, as cited by Singh, 2009, p. 159). However, his struggles to remain in power and keeping true to his word: “...personal weakness and lack of conviction saw corruption reforms go downhill” (Singh, 2009, p. 159). Singh (2009, p. 159) noted that in 2007, numerous scandals implicating senior officials in the government, police and judiciary came to light.

The year 2013 marked an unprecedented election fever, power play and mass use of social media. As soon as Prime Minister Najib Razak called for the $13^{\text {th }}$ general elections to take place on May 5; Malaysians were up in a frenzy craving for a new reformation on various political, economical and social issues breaking BN's iron grip. The surprising performance of BN's opposition, Pakatan Rakyat (PKR or People's Alliance) in the last 
general elections "added new energy to Malaysian politics and powerful voice critical of the incumbent (Nehru \& Tran, 2013, para. 4). In the last general elections, Nehru and Tran (2013, para. 12) acknowledged that PR won nearly half the popular votes (47\%), but it took just over a third (37\%) of the parliamentary seats. Polls indicated that despite Prime Minister Najib Razak's approval rating remained above 60 percent, Nehru and Tran (2013, para. 6) stated the BN coalition was not favoured with an approval rating of only 45 percent. Again, it was no secret; BN had been flooded with many allegations of corruption and cronyism. Nehru and Tran (2013, para. 6) highlighted the issue of land grabs (massive deforestation) in the state of Sarawak, exposing an intricate and systematic corruption that happens in all levels of government in Malaysia.

\section{About Sarawak}

Sarawak is located in the east of the South China Sea and is the largest of Malaysia's 13 states. It is one of the two Malaysian states located on the third largest island in the world - Borneo (Sarawak Government, About, 2013). Popularly known as the Land of the Hornbills, Sarawak is surrounded by the sultanate of Brunei and Sabah (Malaysia) on the north and by Indonesia Borneo (Kalimantan) on the east and south (Encyclopedia Britannica, 2013). Located immediately north of the equator, Sarawak stretches some 800 kilometres along the northwest coast of Borneo and covers an area of 124, 449.51 square kilometers (Sarawak Government, 2013).

According to the latest Population and Housing Census in 2010, Sarawak has an estimated population of over 2.4 million with an annual population growth rate of 1.8 percent (Sarawak Government, The Demographics of Sarawak, 2013). Sarawak is a multicultural state made up of 27 ethnic groups (Sarawak Government, The Demographics of Sarawak, 2013) and other sub-ethnic groups. According to Wonderful Malaysia (2013, para. 7) the three largest ethnic groups-Iban, Bidayuh and Orang Ulu are collectively known as the Dayaks, which means upstream or inland. It is common for these groups to live in longhouses, traditional community homes that are capable of housing 20 to 100 families often times tucked away in the lush tropical rainforest (Wonderful Malaysia, 2013, para. 7).

Sarawak's topography is divided into three regions-coastal lowlands compromising peat swamps as well as narrow deltaic and alluvial plains; a wide are of undulating hills and a mountainous highlands extending to the Kalimantan border (Sarawak Government, The Geography of Sarawak, 2013). With an equatorial climate, humidity is consistently high in the lowlands raging from 80 to 90 percent whereas the temperature in Sarawak ranges from 23 degress Celcius early morning to 32 degrees Celcius during 
the day (Sarawak Government, The Geography of Sarawak, 2013). The highlands have cooler temperatures. Bario's temperatures hovers between 16 to 25 degrees Celcius during the day and gets as low as 11 degrees Celcius on some nights (Sarawak Government, The Geography of Sarawak, 2013). According to the Sarawak Government (The Geography of Sarawak, 2013), the average rainfall per year is between 3,300 millimetres and 4,600 millimetres depending on the region.

Sarawak's main economic drive is its heavy reliance on the abundance of the state's natural resources. The economic structure of Sarawak is largely export oriented, primary commodities such as timber, oil and natural gas including palm oil (forestry, mining and agriculture) dominating the economy. "In 2011, industries involved in the extraction and processing of these commodities contribute about 50\% towards the state's output" (State Planning Unit, Economy, 2013). Lately, the exportation of palm oil is an emerging business for Sarawak and all efforts have been taken to ensure Sarawak's competitive advantage in this economically significant segment of the primary sector. A report from the State Planning Unit of Sarawak (Economy, 2013) reported that in 2011, the production of crude palm oil went beyond 2 million tones, exported primarily to China and India.

\section{Perils of Sarawak's Rainforest}

Borneo is well known among nature lovers, world travelers and environmentalists to be one of the world's most distinct and species rich. The Sarawak Government (The Geography of Sarawak, 2013) reports about “...80 percent or 10 million hectares of Sarawak's total land area is covered with forest (natural as well as secondary forests)."

The remainder 20 percent (2.3 million hectares) is under settlements, towns, agricultural crop cultivation and native customary rights (Sarawak Government, The Geography of Sarawak, 2013).

According to the Department Forest of Sarawak (as cited by Bruno Manser Fund, 2012, p.4) flora in Sarawak includes approximately 8,000 species of vascular plants, 2,000 tree species, 1,000 orchids, 757 ferns and 260 species of palm. "Fauna in Sarawak includes roughly 185 species of mammal, 530 species of bird, 186 species of snake, 104 species of lizard and 113 species of amphibian" (Department Forest of Sarawak, as cited by Bruno Manser Fund, 2012, p. 4).

The United Nations (UN) in 2000 awarded Gunung Mulu National Park, Sarawak's largest national park with a UNESCO World Heritage Site (Sarawak Tourism, Gunung

ECJ Volume 3, No. 1, 2013: The Voice of Change 
Mulu National Park, 2011). This heritage site is important both for its high biodiversity and karst features making it the world's most studied tropical karst area in the world (Sarawak Government, The Geography of Sarawak, 2013). Some of the other accolades Gunun Mulu has received are the world's largest natural chamber, the world's largest cave passage and the longest cave in South East Asia (Sarawak Tourism, Gunung Mulu National Park, 2011).

In September 2011, a freelance reporter Jeswan Kaur criticized the UN through its Millenium Development Goals (MDGs) 2010 report for praising the state of Sarawak on a "job well done" in addressing issues of human rights abuse and environmental damage (Kaur, 2011, para. 1). Kaur claimed that under the corrupt leadership of Chief Minister Taib Mahmud, he has refused to promote gender equality and empower women, “... as seen from the never-ending rapes of the Penan women and girls by timber loggers" (Kaur, 2011, para. 7). She further argued that under the leadership of Taib, continous logging activities have disrupted the lives of the natives, with loggers boldly encroaching native lands, which have been snatched for logging, mining and plantation purposes.

Kaur (2011, para. 19) reported that it was a stark contrast to the Malaysian 2008 annual auditor-general's report that deemed the state government of Sarawak's forest management was unsatisfactory. Despite Chief Minister Taib's claims that 70 percent of Sarawak's rainforest is still intact while 14 percent of its "secondary forests" have been replanted or are in the process of being converted to plantations, Butler (2011, para. 1) reported that satellite images from Google Earth showed a stark contrast between forest cover in Sarawak and its Borneo neighbours. Butler (2011, para. 3) further affirmed that the images appear to support claims from environmentalists with some groups estimating Sarawak has experienced a loss of 90 percent of its primary forest cover. Forests that remain have been selectively but heavily logged approximately two or three times over in the past 30 years according to Butler (2011, para. 3). He added these forest areas have been converted for timber, wood-pulp and timber plantations.

In June 2013, Sukumaran a reporter for The Star Online, published an article stating that Malaysia saw an increase of 115 percent in deforestation during the first three months of 2013 (2013, para. 1). This report was made according “... to a forest tracking tool developed by National Aeronautics and Space Administration (NASA) researchers" (Sukumaran, 2013, para. 1). Sukumaran (2013, para 2) further reported that Malaysia led the way by being the top country where deforestation was rampant followed by Nepal (114\%), Mexico (92\%), Argentina (72\%) and Madagascar (51\%). In an interview, Christopher Potter, a senior research scientist at NASA Ames Research Centre told 
Sukumaran (2013, para 4) that numerous areas in Sarawak have been detected with forest cover change over the past two years.

Britain's former Prime Minister in 2011, condemned the destruction of Sarawak's rainforest stating is, "probably the biggest environmental crime of our times... Malaysia's once vast pristine jungle has been stripped bare and enormous areas have been planted with oil palm in an environmental nightmare that shows no sign of slowing" (Brown, as cited by Bruno Manser Fund, 2012, p. 4). Kaur (2011, para. 9) blamed Taib’s increasing greed is the man responsible for the rapid balding of Sarawak's rainforest, no thanks to the continuous logging carried out by his cronies.

\section{Who is Chief Minister Taib Mahmud?}

Chief Minister Pehin Sri Haji Taib Mahmud a native of Sarawak is the fourth Chief Minister of the state. He currently holds the portfolio of the state Minister of Finance and the Minister of Planning and Resource Management (The Chief Minister of Sarawak, 2013, para 1). In addition he is the President of Parti Pesaka Bumiputera Bersatu (PBB) and chairman of the state Barisan Nasional (The Chief Minister of Sarawak, 2013, para. 1).

With a background in law, Taib held various ministerial positions ranging from Minister of Development and Forestry of Sarawak in 1966 and several federal portfolio positions such as Minister of Primary Industries in 1972, Minister of General Planning and Socio-Economic Research in 1974 and Minister of Primary Industries (The Chief Minister of Sarawak, 2013, para. 3-4). At the age of 45, in 1981, Taib was appointed to be the Chief Minister of Sarawak, which currently makes him Sarawak's longest-serving chief minister (The Chief Minister of Sarawak, 2013, para. 5).

Taib has four children with his late wife Laila Chalecki Taib, they are Jamilah Hamidah Mahmud, Abu Bekir, Sulaiman Abdul Rahman and Hanifar Hajar (Chief of Sarawak, 2013, para. 6). Taib remarried in December 2010 to Puan Sri Raghad Kurdi Taib (Chief of Sarawak, 2013, para. 6).

Taib's various ministerial positions no doubt puts him in immense political and economic power. Nevertheless, his official payroll per year as Chief Minister of Sarawak, MYR 590, 000 (USD 194, 000), Taib is known for his abundance in wealth and string of assets as reported by the Bruno Manser Fund (2012, p.9). Hazis (as cited by Bruno Manser Fund, 2012, p. 9) pointed out that Taib is often seen travelling in a Rolls Royce, adorned in a designer suit, wearing a walnut-sized ruby ring and as Aeria noted (as cited 
by Bruno Manser Fund, 2012, p. 9) Taib resides in a well-guarded palace like mansion in Kuching, the capital city of Sarawak. Such is the lifestyle of Taib that during a 2010 election campaign, he unabashedly told rural voters in Sarawak, "I have more money than I can ever spend," reported by the Democratic Action Party Sarawak (as cited by Bruno Manser Fund, 2012, p. 9).

For over thirty years, Taib Mahmud has methodically harvested a country once rich in natural resources, particularly oil, gas and timber. "While the proceeds of the oil and gas extraction are mostly benefiting Malaysia's federal government, the Sarawak state government enjoys total autonomy as to the use of the state's forest resources and state lands" (Bruno Manser Fund, 2012, p. 9). It is reported by Lim (2012, para. 5) that Taib has amassed a personal wealth of MYR 46 billion (USD 15 billion) making him Malaysia's richest man outstripping tycoon Robert Kuok who has USD 12.5 billion.

The exposé by the Swiss-based NGO Bruno Manser Fund (BMF) directly pinpoints Taib playing a principal role of corruption and abuse of public funds to enrich himself, his family and his political allies through land appropriation and destructive logging of the rainforest in Borneo (2012, p. 12). One of the earliest corruption scandals to come into the limelight was in 2007. A letter by several Japanese non-governmental organizations and citizen's groups in Malaysia was sent to the then Prime Minister of Malaysia Ahmad Badawi concerning a defamation suit and threats against them by Taib and his family accused of receiving kickbacks. A report was published in the Japan Times on March 29 alleged that nine Japanese shipping companies which transported lumber from Sarawak failed to report some 1.1 billion yen (approximately MYR 32 million) in income paid as remuneration to Regent Star, a Hong Kong based agent with connections to Taib and his family, over a duration of seven years (Letter to Malaysian PM, 2007).

In 2008, Tribun Pontianak (as cited by Burno Manser Fund, 2012, p. 13) an Indonesian newspaper reported that approximately 30 shipments of illegal Indonesian logs were imported into Sarawak and re-exported to other countries every month. Naturally, Taib's name was dragged into this timber scam. Lukas Straumann an advocate with the Bruno Manser Fund attested, "We know from satellite imagery that less than 10\% (possibly less than 5\%) of Sarawak's forests are still intact" (Butler, 2011, para 10). Yet, with Taib's multi-billion dollar industrialization project "Sarawak Corridor Renewable Energy" (SCORE), it is set to see 50 hydroelectric dams, palm oil plantations, smelter plants and mining projects displace tens of thousands indigenous people (Bruno Manser Fund, 2012, p. 13). These projects no doubt are being widely opposed as 
reported by The Star (as cited by Bruno Manser Fund, 2012, p. 13) by local communities who are against environmental destruction of their land and government linked corruption. Without a doubt, the people who would be reaping the fruits of this grand money making scheme are the Taib family and their close political allies.

In August 2011, an independent media outlet known as Sarawak Reporter exposed Taib's USD \$5 million a year contract with a British based PR company FBC media to conduct a global media campaign in his favour (Bruno Manser Fund, 2012, p. 13). Sarawak Reporter disclosed (as cited by Bruno Manser Fund, 2012, p. 14) that many reputable broadcasting agencies such as $\mathrm{BBC}, \mathrm{CNBC}$ AND CNN were implicated in this scandalous campaign. According to BBC World (as cited by Bruno Manser Fund, 2012, p. 14) both $\mathrm{CNBC}$ and $\mathrm{BBC}$ have made public apologies since. As of late many broadcast channels have aired exposés of the hierarchical and systematic corruption in the state of Sarawak. Some of these channels as the Bruno Manser Fund (2012, p. 14) states include ABC, Al-Jazeera, Canadian Global News, Australia's SBS One Dateline, The Independent, Guardian, The Sunday Times, Daily Mail, The Economist, Evening Standard and Global Witness.

\section{The First Family of Sarawak}

The BMF report entitled 'The Taib Timber Mafia: Facts and Figures on Politically Exposed Persons from Sarawak, Malaysia' was published in 2012. According to Lim (2012, para. 6), it is the first report of its kind that describes in detail the business activities and personal wealth of 20 members of the Taib family in Malaysia, Australia, Canada, Hong Kong, United Kingdom, United States and other countries. BMF bravely disclosed the net worth of the Taib clan to be an estimated USD $\$ 21$ billion, “... spread over 400 companies around the glove-all built through their near complete political and economic control of Sarawak, which has been reduced from one of the richest to one of the poorest states in Malaysia over three decades" (Lim, 2012, para. 9). Lim (2012, para. 8) remarked the BMF report was a means to build international pressure against the Sarawak's first family and provide investigating bodies, journalists, Sarawakians and interested parties with hard evidence on the Taib financial empire.

In March of 2013, prior to Malaysia's $13^{\text {th }}$ General Elections, Malaysians were confronted with an exposé made by Global Witness. It was a 15 minute documentary

entitled 'Inside Malaysia's Shadow State: Backroom deals driving the destruction of Sarawak." Many Malaysians were outraged and taken by surprise of how the intricacies of corruption, cronyism and nepotism were happening in the state of Sarawak. 
Malasysian Today (2012, para. 11) explained Global Witness posed as foreign investors looking to buy land for oil palm plantations and was approached by the Regional Corridor Development Authority (RECODA), the government body charged with receiving foreign investment. However, as Global Witness reported $(2012$, p. 1) the investigative reporter was redirected to certain members of Taib's family looking to sell a company licensed to $\log$ and clear land for plantations in the state. Global Witness continued (2012, p. 1) a total of four land leases was offered and to their discovery, members of the Taib's family were direct shareholders in or beneficial owners of three of those land leases. "...while the fourth deal was, according to an intermediary, proposed on the understanding that Taib would receive a multimillion dollar kickback from the selling party" (Global Witness, 2012, p. 1). Global Witness (2012, p. 1) summed up their main findings in Sarawak, kickbacks, corrupt land deals, evasion of Malaysian tax and the service of economy of corruption were true and evident.

The findings also reveal the elitist family of Taib "... have a deep seated contempt for Sarawak's indigenous population, whose rights to their ancestral land are enshrined in Sarawak's law and protected under the Malaysian constitution" (Malaysia Today, 2012, para. 14). As Malaysia Today noted (2012, para. 14), two of Taib's first cousins who appeared in the documentary, repeatedly referred to indigenous communities as "naughty" people who "try to make money" through "squatting" on land that has been licensed to private companies for logging and plantations.

Tom Picken, Forest Team Leader at Global Witness asserted, "The Taib family and their friends have treated Sarawak's natural resources like a personal piggy bank for decades" (Malaysia Today, 2012, para 15). Picken (as cited by Malaysia Today, 2012, para. 15) further added:

This investigation shows how they are willing to stash this dirty cash in jurisdictions like Singapore, which one lawyer in the film describes as "the new Switzerland". Until Singapore and other financial service centres stop allowing corrupt politicians and criminals to shield themselves and their loot from justice back home, the likes of Taib will continue to get away with stealing from their own people.

However, the "piggy bank" doesn't stop there, in fact thanks to the investigative reporting of Sarawak Reporter and Global News' 16x9 the paper trail leads right to Taib's eldest child Jamilah Taib who is also a Canadian citizen and currently resides in Ottawa with her husband Sean Murray. 


\section{Princess Jamilah - the Canadian Connection}

Jamilah Hamidah Taib-Murray is the eldest of Taib's four children. The Bruno Manser Fund (2012, p. 26) said she studied business management at Carlton University in Ottawa, Canada and met her husband Sean Murray there. Sarawak Report (as cited by Harakah Daily, 2013, para. 1) reported that Jamilah, was dubbed "Princess Jamilah" by her fellow students whilst still at Carlton because of her immense wealth. It was further revealed by Sarawak Reporter that Jamilah had started a huge property company called Sakto Development Corporation in Canada when only a student in 1983 (as cited by Harakah Daily, 2013, para. 4).

Bruno Manser Fund (2012, p. 26) reported with an estimated net worth of USD \$1 billion, Jamilah is a director of four companies and shareholder of at least another 86 companies. As Industry Canada stated (as cited by Bruno Manser Fund, 2012, p. 26) several companies from the Sakto group are still being directed by Jamilah and her husband. Meanwhile Companies House (as cited by Bruno Manser Fund, 2012, p. 26) reported that Sakto's British sister company, Ridgeford Properties, in London is being managed by Sean and her in-laws. The Taib family in a legal statement by one of Britain's top lawyers they hired, Reya (as cited by Bruno Manser Fund, 2012, p. 26) declared that Sakto and Ridgeford along with another company Sakti (managed by her sister) are not funded by Taib Mahmud. However, Taib contradicted that very statement in an infamous video posted online as Sarawak Reporter posted (as cited by Harakah Daily, 2013, para. 7) that he started Jamilah up in business during the 80s with a small "nest egg” he'd received as retirement payment from his term as a Federal Minister.

Jamilah and Sean are well known elite socialites, often invited as guests at Ottawa's high society parties. The Bruno Manser Fund reported (2012, p. 26) Jamilah and Sean reside in a mansion in Rockcliffe Park, Ottawa, which was named the city's second most expensive hosue in 2009, estimated at 9.6 million Canadian dollars. Prentice acknowledged (as cited by Bruno Manser Fund, 2013, p. 26) the house is reputed to be lavishly clad in marble, with chandeliers and cathedral-like ceilings. Sarawak Reporter noted (as cited by Harakah Daily, 2013, para. 17) that Jamilah is rarely seen sporting the same over-sized jewels or couture twice and he children tweet about ponies, sailing and holidays in the well-known off shore tax haven of the British Virgin Islands.

In December 2011, Canada's Global News ran an investigative piece entitled "Family Trees" in their prime time 16x9 show. The investigation was about the alleged money trail between Sarawak's Chief Minister and his family in Canada. It also featured Jamilah and Sean's property portfolio in Canada, USA and London and as Global News 
reported (as cited Bruno Manser Fund, 2012, p. 27) despite being approached by the show, the couple refused to be interviewed.

Global News also featured Clare Rewcastle Brown, a native of Sarawak who now resides in London and is an investigative reporter. "She writes about the environment in Sarawak and what she sees as political connections to the destruction of the land on her blog, The Sarawak Report" (Global News, 2011, para. 2) and Radio Free Sarawak, an independent radio station.

\section{The Sarawak Report and Clare Rewcastle-Brown}

The campaign against Chief Minsiter Taib and his family has been led by Clare Rewcastle Brown, the sister in law of British former Prime Minister Gordon Brown, who run the Sarawak Report and Radio Free Sarawak as stated by Butler (2011, para. 7). "Through internet postings and shortwave radio transmission from London, Rewcastle Brown has given voice to growing concerns among Malaysians about environmental degradation" (Mullany, 2013, para. 2).

Rewcastle Brown, 54, was the daughter of a police officer in Sarawak during colonial days and has vivid memories of the vast canopy of the rainforest in Borneo she tells Mullany of The New York Times (2013, para. 5-6). A former journalist at BBC World Service, ITV News and Sky Television in London, she was appalled at the destruction of forests when she returned to Kuching in the 2000s for an environmental conference (Mullany, 2013, para. 7).

As posted on Sarawak Report, the website "...exists to provide that platform and to offer an alternative vision of justice, transparency and a fairer future in Sarawak" (Sarawak Report, 2013, para. 5). In her interview with Mullany, she explained that with the aid from the Bruno Manser Fund - named after a Swiss environmental activist who disappeared in Malaysia in 2000 and is presumed dead- Rewcastle Brown started the Sarawak Report in 2010 (2013, para. 11). With a collaboration of other writers, Sarawak Report started out publishing investigative reports in English for a Malaysian audience. Her next project was Radio Free Sarawak, “... helped along by a drive that put 10,000 shortwave radios in the hands of Malaysians to hear the broadcasts, an effort aided by local churches and opposition groups" (Mullany, 2013, para. 8). She further shared with Mullany that families would sit together in verandas to listen to these broadcasts and to increase their audience reach, Sarawak Radio moved their broadcasts later in the day to accommodate workers coming home from rice paddies (2013, para. 9). 
Both these media outlets not only highlights the deforestation and the corruption taking place in Sarawak, but in addition champions human rights and social economic issues that plague indigenous tribes in Sarawak. World famous anthropologist, Wade Davis told 16x9 that one of the last nomadic tribes the Penan are in danger of having their homes wiped out. He said, "Within a single generation a way of life, morally inspired and inherently right, was being crushed just as the forest in which they were born was being crushed...There was something incredibly unjust about that" (Global News, 2011, para. 4).

Kaur (2011, para. 10) also noted for over a decade, the women and girls from the Penan community have been trying to seek help from the federal government and the police from being continuously raped by the timber loggers. "These timber loggers have never been hauled up as corruption and nepotism run deep among the "powers that be" in Sarawak, with Taib leading the entourage of Sarawak's politician-cum-marauders" (Kaur, 2011, para. 11).

Rewcastle Brown acknowledges the fact that Malaysians themselves are not as free to do such reporting despite being in a country that exercises democratic rights however exerts strong controls on news media, "They'd be arrested immediately and their livelihoods would be destroyed” (Mullany, 2013, para. 4). Bridget Welsh, a political science professor at Singapore Management University and an expert on Malaysian affairs, told Mullany (2013, para. 19-20) the two news outlets have greatly impacted Taib's leadership in the urban areas, especially among the Chinese, the more educated and internet connected. However, Welsh believes that the deforestation will continue, as "the elite in Malaysia are concerned with making money" (Mullany, 2013, para. 20).

Rewcastle Brown inspired by the work of Manser when she began her investigative work looking into the deforestation of Sarawak, does not regret her move into opposition journalism, "I must try to do something...I'll never forgive myself if I don't try” (Mullany, 2013, para. 22-23).

\section{The Significance of a Power Shift in the $13^{\text {th }}$ General Elections}

When Global Witness exposed the controversial documentary of the shady dealings of land grabs in Sarawak, Sta Maria (2013, para. 5) reported the video had sparked protests among 300 Bidayuhs, Ibans and Malays as they were outraged by Taib's cousins' degrading remarks. See Chee How, Pakatan Rakyat's state election operation director agreed it made a strong impact on Sarawakians however he told Sta Maria he was still unsure if it was enough to end BN's rule in the state (2013, para. 7).

ECJ Volume 3, No. 1, 2013: The Voice of Change 
In the same interview by Sta Maria, Professor Jayum anak Jawan, warned the opposition to be not overly dependent on Global Witness for a win (2013, para. 8). A native of Sarawak and Deputy Dean of University Putra Malaysia's Faculty of Human Ecology explained the video will only impact the urbanites (2013, para. 9). Sta Maria reported (2013, para. 9) Jayum further asserted that these urbanites have already made up their minds on who to vote for and the video merely reaffirms their choice. He also emphasized the diverse political patterns that exist between urban and rural voters, "Rural voters are dependent on small handouts and are removed from national issues" (Sta Maria, 2013, para. 10).

Many of the indigenous communities live right in the heart of the rainforest of Sarawak therefore do not have access to the modern forms of media or technology or access is limited. Da Silva's research in the remote regions of Ecuador proved that "A separation in technology eventually leads to a separation in community as individuals go unheard, and unnoticed" (2012, p. 9).

As noted, Sarawak remains to be one Malaysia's poorest states and suffer from a high social inequality. How then are Sarawakians going to come together to fight on sustaining their rainforest, human rights, social and economic issues? Definitely not while Taib and his elitist family members and friends stay in power. The situation that is happening in Sarawak leads to Wilkinson's (2010, p. 134) theory proving that social inequality leads to negative social and health outcomes. "Because people are less out for themselves in more equal societies, the higher levels of trust and involvement in community life suggest they are more public spirited. So, greater equality is likely to make an important contribution to sustainability" (Wilkinson, 2010, p. 134).

Jayum commented that Sarawakians were more invested in state elections than the federal elections. "State elections are about the configuration of state power and leadership" (Sta Maria, 2013, para. 22). He told Sta Maria (2013, para. 23) they are more interested in who controls Sarawak at the end of the day than who represents them at the Federal level. Sta Maria (2013, para. 24) reported that Jayum described the election in Sarawak is an "awakening" that will bring hope to rural voters by showing them that they have alternative when choosing parliamentary representatives. His personal wish was to see a winning coalition with a less than two-third majority saying, "Two thirds would be too powerful and will make them forget that they are working for the people" (Sta Maria, 2013, para. 27). 


\section{Election Outcomes}

On May 6, 2013 Malaysia's long governing coalition Barison Nasional won the $13^{\text {th }}$ General Elections. CBC News (2013, para. 3) reported the elections had exposed "the entrenched racial divide in the country but also a new schism-between the rural poor who preferred the status quo and the urban middle-class who wanted change."

CBC News reported that despite having lost its popularity vote, nevertheless it seems $\mathrm{BN}$ had done well by winning 133 seats in the 222 member parliament-down to a fraction from the 135 it won in 2008 (2013, para 5). BN had banked heavily on three states with large rural populations to which Sarawak was one of them. "...many people from indigenous groups and ethnic Malay majority are beholden to the government for handouts traditionally given to them" (CBC News, 2013, para. 7).

It was no secret that $\mathrm{BN}$ benefited from gerrymandering of constituencies. In Sarawak, nearly all six constituencies won by opposition had between 26,000 and 40,000 voters each as reported by CBC News (2013, para. 13). "In contrast, only two of the National Front's 20 parliamentary seats in Sarawak had that many people vote on Sunday" (CBC News, 2013, para. 13).

Welsh affirmed, "What we are seeing here is a regime that has used the trappings of power to stay in power" (CBC News, 2013, para. 13). What does this mean for the future of Sarawak's rainforest and its people? As long Taib and his family remain in power the words of Welsh seems to hold true of Sarawak's future "...that the deforestation will continue, as "the elite in Malaysia are concerned with making money" (Mullany, 2013, para. 20).

It would be the brave activists such as Rewcastle Brown, her colleagues along with other environmentalists, human rights and political advocates to stop the rape of Sarawak's rainforest and its indigenous people of suffering from a 'silent death.'

* Author: Tisha Raj is a fourth year student at MacEwan University majoring in Sociology, specializing in family, youth \& diversity with a minor in political science. She considers herself to be a feminist, a keener on the issues of sustainability and a passionate advocate for social justice. She has ambitions of one day being a full time globe trotter. 


\section{References}

Admin-s (2013, March) Inside Malaysia's shadow state. Malaysia Today. Retrieved from http://www.malaysia-today.net/mtcolumns/special-reports/55219-insidemalaysias-shadow-state

Bruno Manser Fund. (2012). The Taib timber mafia: facts and figures on politically exposed persons (PEPs) from Sarawak, Malaysia. Retrieved from http://www.stoptimber-corruption.org/resources/BMF_Taib_family_report_2012_09_20.pdf

Butler, R.A. (2011, March). Google Earth reveals stark contrast between Sarawak's damaged forests and those in neighbouring Borneo states. Mongabay.com. Retrieved from http://news.mongabay.com/2011/0328-sarawak_google_earth.html

da Silva, S. (2012). Communication Breakdown: The Media Effects on Ecuador's Environment. Earth Common Journal, 2 (1), 1-11. Retrieved from https://journals.macewan.ca/index.php/earthcommon/article/viewFile/67/73

Global Witness. (2013, March). Inside Malaysia's shadow state: Backroom deals driving the destruction of Sarawak. Globalwitness.org Retrieved from http://www.globalwitness.org/sites/default/files/library/InsideMalaysia $\% \mathrm{E} 2 \% 80$ $\% 99$ s-Shadow-State-briefing.pdf

Kaur, J. (2011, September). UN report praising Sarawak is pure fiction. Free Malaysia Today. Retrieved from http://www.freemalaysiatoday.com/category/opinion/2011/09/27/unreport-praising-sarawak-is-pure-fiction/

Letter to Malaysian PM: Corruption allegations against Sarawak CM Taib Mahmud and Portal. Retrieved from http://www.illegal-logging.info/content/letter-malaysianpm-corruption-allegations-against-sarawak-cm-taib-mahmud-and-freedom

Lim, K.S. (2012, September). INCREDIBLE: How can Najib ignore \& even give the SIGNAL not to investigate Taib! Malaysian Chronicle. Retrieved from http://www.malaysia-

chronicle.com/index.php?option=com_k2\&view=item\&id=41388:inc \#axzz2fbBEt OdQ

Mullany, G. (2013, August). Barred from Malaysia, but still connecting with critical jabs. The New York Times. Retrieved from http://www.nytimes.com/2013/08/17/world/asia/barred-from-malaysia-but-stillconnecting-with-critical-jabs.html?_r $=1 \&$ 
Nehru, V. \& Tran, V. (2013, April). Understanding Malaysia’s Pivotal General Election. Carnegie Endowment for International Peace. Retrieved from http://carnegieendowment.org/2013/04/10/understanding-malaysia-s-pivotalgeneral-election/fyxs

Official website of the Chief Minister of Sarawak. (2013, August). Pehin Sri Haji Abdul Taib Mahmud - Profile of the Chief Minister. Retrieved from http://chiefministertaib.sarawak.gov.my/en/chief-minister-of-sarawak/profile

Sarawak. (2013). In Encyclopedia Britannica. Retrieved from http://www.britannica.com/EBchecked/topic/524035/Sarawak

Singh, B. (2009). Malaysia in 2008: The Elections That Broke the Tiger's Back. Asian Survey, 49(1), 156-165. Retrieved from http://www.jstor.org/stable/10.1525/as.2009.49.1.156

Sukumaran, T. (2013, June). Nasa: Malaysia sees 115\% jump in deforestation in first 3 months of 2013. The Star Online. Retrieved from http:/ /www.thestar.com.my/story.aspx?file $=\% 2 \mathrm{f} 2013 \% 2 \mathrm{f} 6 \% 2 \mathrm{f} 21 \% 2$ fnation $\% 2 \mathrm{f} 20$ 130621081124\&sec $=$ nation\#.UcPUL5eDEoo.twitter

The Associated Press (2013, May). Malaysia's election results exposes divided country. CBC News World. Retrieved from http://www.cbc.ca/news/world/malaysia-selection-result-exposes-divided-country-1.1344840

The Economist. (2008, March). Malaysia's election. Political tsunami? A threat to the prime minister. Retrieved from http://www.economist.com/node/10833119

The official portal of the Sarawak government. (2013, July). About. Retrieved from http://www.sarawak.gov.my/en/about-sarawak

The official portal of the Sarawak government. (2013, July). Demographics. Retrieved from http://www.sarawak.gov.my/en/about-sarawak/demographics

The official portal of the Sarawak government. (2013, July). Geography. Retrieved from http://www.sarawak.gov.my/en/about-sarawak/geography

The official website for the state planning unit. (2013, June). Economic outputs. Retrieved from http://www.spu.sarawak.gov.my/economy.html

Wilkinson, R. (2010). Inequality and social outcomes-the journey to spirit level and beyond: an interview. International Journal Management Concepts and Philosophy, 4 (2), 126-136. 
Wonderful Malaysia. (2013). Tribes on Borneo (Sarawak \& Sabab). Retrieved from http://www.wonderfulmalaysia.com/malaysia-population-and-demographics.htm 